\title{
Tinjauan Aksesibilitas pada Fasilitas Umum bagi Pengunjung dengan Alat Bantu Berjalan Studi Kasus Mall Bandung Indah Plaza
}

\author{
Anastasha Oktavia Sati Zein \\ Jurusan Desain Interior, Institut Teknologi Nasional, Bandung \\ Jl. PKH. Hasan Mustapa No. 23 Bandung 40124 \\ Email: tashazein@yahoo.com
}

\begin{abstract}
ABSTRAK
Seтua manusia membutuhkan kemudahan dalam mencapai suatu tempat, terutama bagi orang yang memakai alat bantu berjalan. Fasilitas ini sebaiknya terdapat tidak hanya dilingkungan dimana mereka hidup seharihari tetapi juga harus di sediakan pada bangunan umum seperti aktifitas bekerja dan aktifitas rekreasi.

Kemudahan aksesibilitas pada fasilitas umum ini memungkinkan pengunjung dengan alat bantu berjalan untuk bersosialisasi dengan orang lain diluar dari lingkungan keluarganya.
\end{abstract}

Kata kunci: Aksesibilitas, Pengguna Alat Bantu Berjalan, Pusat Pertokoan

\section{ABSTRACT}

Everybody needs facility to reach every place with ease, especially to those who require walking aids. This facility not only be found in their surroundings but also provided in the public facility such as work place and recreation activity.

The easiness accessibility in the public facility allows visitors with walking aids to socialize with others outside their surroundings.

Keywords: Accessibillity, Walking Aids User, Mall 


\section{PENDAHULUAN}

Aksesibilitas adalah kemudahan yang disediakan bagi semua orang terutama bagi penyandang disabilitas dan lansia guna mewujudkan kesamaan kesempatan dalam segala aspek kehidupan dan penghidupan[1]. Kemudahan akses seharusnya diterapkan terutama pada sarana - sarana umum yang memadai dan berkesinambungan sehingga tercapai kemandirian dan kesejahteraan.

Pengunjung dengan alat bantu berjalan yang dibahas pada penelitian ini adalah pengunjung dengan alasan usia dan penyandang difabel. Yang dimaksud dengan usia disini adalah suatu tingkat usia tertentu yang tidak memungkinkan orang tersebut untuk berjalan tanpa alat bantu, seperti bayi dan orang lanjut usia. Sementara pengertian difabel menurut WHO (World Health Organization) adalah suatu ketidaknormalan yang bersifat fisiologis, psikologis maupun gabungan dari keduanya[2]. Ketidaknormalan tersebut dapat mengakibatkan seorang penyandang difabel kesulitan dalam melakukan aktifitas kesehariannya, sehingga membutuhkan bantuan dari lingkungan yang berupa bantuan dari orang lain maupun penyesuaian fasilitas disekitar lingkungannya.

Pada penelitian ini akan membahas mengenai aksesibilitas pengunjung dengan alat bantu berjalan pada fasilitas umum berupa pusat pertokoan atau mall. Mall BIP atau Bandung Indah Plaza merupakan salah satu pusat perbelanjaan tertua di Bandung yang diresmikan pada tahun 1990 dan terletak di jalan Merdeka. Mall ini telah melewati beberapa kali renovasi juga pergantian menajemen yang berpengaruh pada perluasan bangunan sehingga sampai pada bentuknya yang sekarang[3]. Fasilitas yang memudahkan aksesibilitas ini penting untuk ditinjau karena masih belum lengkapnya pengadaan fasilitas tersebut terutama pada bangunan publik, dimana seharusnya tidak ada pembedaan. Seperti tercantum pada Undang - Undang Republik Indonesia No 8 Tahun 2016 mengenai penyandang disabilitas yang tertulis pada pasal 18 yang menyebutkan bahwa penyandang difabel berhak mendapatkan aksesibilitas untuk memanfaatkan fasilitas publik guna mewujudkan kesamaan kesempatan[4]. Selain itu juga menurut Sensus Penduduk, Pusat Data dan Informasi Kementrian Kesehatan RI pada tahun 2010 di Jawa Barat terdapat 206.094 penduduk kesulitan berjalan dengan tingkat sedang dan 105.555 penduduk kesulitan berjalan dengan tingkat parah[5]. Data di atas diluar dari pengunjung dengan alat bantu berjalan karena kecelakaan, orang tua dan balita sehingga mengharuskan mereka untuk menggunakan alat bantu tersebut. Berdasarkan data tersebut semakin memperjelas betapa pentingnya kemudahan fasilitas untuk orang dengan keterbatasan dan pengunjung dengan alat bantu berjalan pada fasilitas umum.

\section{METODOLOGI}

Metodologi yang digunakan dalam tulisan ini adalah analisis deskriptif kualitatif, dengan melakukan observasi lapangan dan dokumentasi foto, untuk kemudian data tersebut dianalisa melalui teori desain yang berhubungan dengan aksesibilitas vertikal atau kemudahan pencapaian di tiap tingkat pada pusat pertokoan yang melingkupi eskalator, ram dan lift.

Alat bantu berjalan yang umumnya digunakan pengunjung mall dapat berupa kursi roda, tongkat berjalan, tongkat ketiak atau kruk dan kereta bayi. 

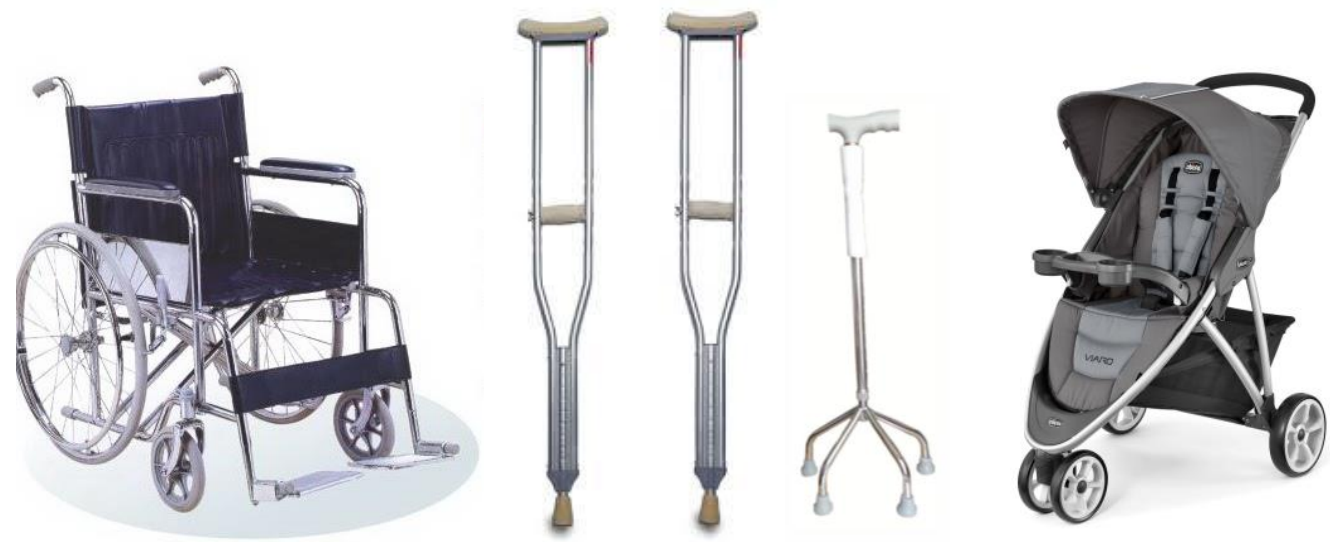

Gambar 1. Contoh alat bantu berjalan[6]

Pada waktu penggunaan tongkat berjalan dan kruk tidak memakan tempat yang besar karena posisi pengguna masih dalam keadaan berdiri, sementara untuk kursi roda dan kereta bayi membutuhkan area yang cukup luas pada waktu berjalan dan manuver (berbelok arah) karena mempunyai dimensi lebih besar daripada tongkat. Walaupun prosentase penggunaan kursi roda dan tongkat berjalan di dalam mall relatif kecil bila dibandingkan dengan pengunjung lain, pengguna kereta bayi sangat umum ditemukan di setiap pertokoan besar, tidak terkecuali di BIP ini, karena sekarang fungsi dari mall bukan hanya sebagai pusat perbelanjaan saja tetapi juga sebagai tempat untuk bertemu orang, jalan - jalan dengan keluarga dan berbagai rekreasi lainnya.

Menurut Keputusan Menteri Pekerjaan Umum RI No.468/KPTS/1998 mengenai persyaratan teknik aksesibilitas pada bangunan umum dan lingkungan, pada prinsipnya setiap bangunan wajib memenuhi 4 azas aksesibilitas[7], yaitu:

a) Kemudahan, yaitu setiap orang dapat mencapai semua tempat atau bangunan yang bersifat umum dalam suatu lingkungan.

b) Kegunaan, yaitu setiap orang harus dapat mempergunakan semua tempat atau bangunan yang bersifat umum dalam suatu lingkungan.

c) Keselamatan, yaitu setiap bangunan yang bersifat umum dalam suatu lingkungan terbangun, harus memperhatikan keselamatan bagi semua orang.

d) Kemandirian, yaitu setiap orang harus bisa mencapai, masuk dan mempergunakan semua tempat atau bangunan yang bersifat umum dalam suatu lingkungan dengan tanpa membutuhkan bantuan orang lain.

\section{ANALISA DAN PEMBAHASAN}

Mengacu dari azas tersebut, sebuah bangunan publik selayaknya menerapkan hal - hal di bawah ini sehingga azas yang di syaratkan pemerintah mengenai kebutuhan aksesibilitas untuk pengunjung dengan alat bantu berjalan terpenuhi[7] \& [8]:

1. Ram / Jalur melandai

Ram merupakan jalur melandai yang digunakan bagi orang yang tidak dapat memakai anak tangga. Penggunaan ram ini dipakai mulai dari luar bangunan sampai dengan di dalam bangunan. 

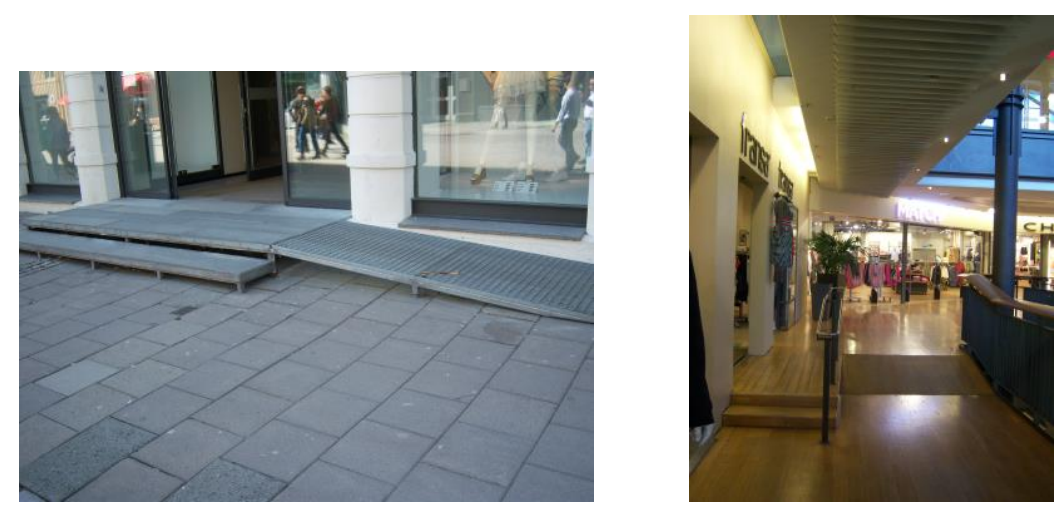

\section{Gambar 2. Contoh penggunaan ram di luar \& di dalam bangunan pertokoan}

Yang perlu diperhatikan pada jalur melandai adalah:

- Pemakaian ram di luar bangunan harus mempunyai permukaan kasar untuk menghindari licin.

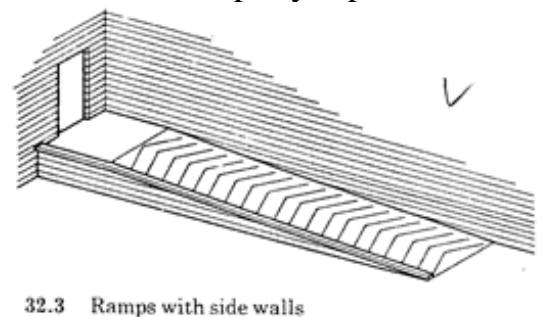

\section{Gambar 3. Contoh ram dengan permukaan kasar[8]}

- Panjang ram tidak boleh lebih dari $900 \mathrm{~cm}$, sedangkan untuk pemakai kursi roda membutuhkan lebar $100 \mathrm{~cm}$ dan maksimal panjangnya $10 \mathrm{~m}$, apabila level masih jauh dari 10 $\mathrm{m}$, maka dibutuhkan bordes atau tempat istirahat yang datar. Derajat ram yang dibutuhkan adalah 5 derajat.

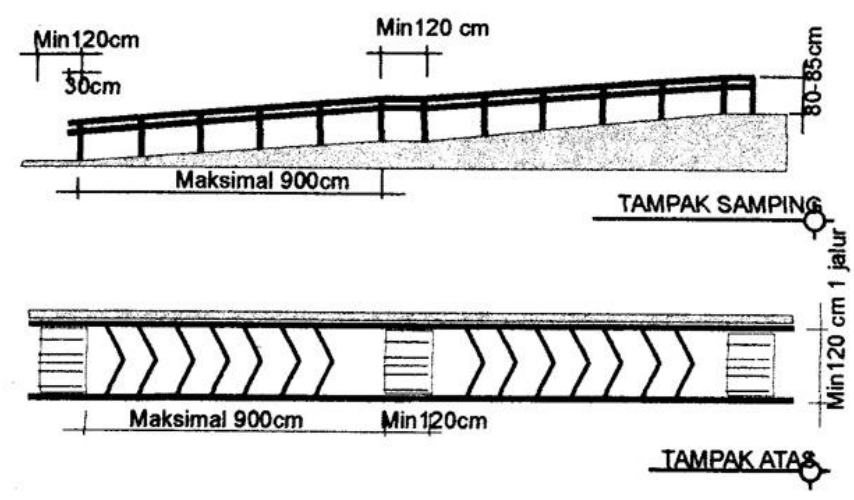

Gambar 4. Standar ukuran ram[7]

- Pegangan tangan atau handrail dibutuhkan setidaknya pada satu sisi ram untuk menopang beban tubuh pada saat naik - turun. Tinggi pegangan tangan dari permukaan ram $65 \mathrm{~cm}$ untuk anak - anak dan $80 \mathrm{~cm}$ untuk orang dewasa.

2. Lift

Lift merupakan alat mekanis elektrik berupa ruang untuk berpindah tingkat vertikal lebih tinggi atau lebih rendah. Yang perlu diperhatikan pada lift adalah :

- Bangunan yang terdiri lebih dari 5 lantai maka harus tersedia lift yang aksesnya mudah.

- Lebar minimal area untuk menunggu lift datang adalah $185 \mathrm{~cm}$.

- Ukuran ruang lift minimal $140 \mathrm{~cm}$ x $140 \mathrm{~cm}$ sehingga dapat memuat pengguna kursi roda, mulai dari masuk melewati pintu lift, gerakan memutar, menjangkau panel tombol dan keluar melewati pintu lift. 


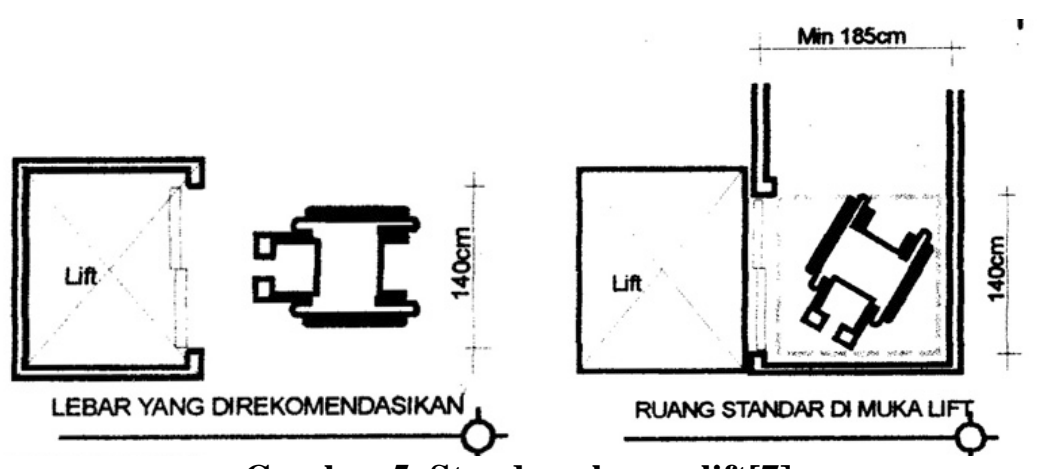

Gambar 5. Standar ukuran lift[7]

\section{Mall Bandung Indah Plaza}

Mall yang terletak dipusat kota Bandung, tepatnya di jalan Merdeka No. 56. Bangunan ini terdiri dari 4 lantai pertokoan (Ground Floor/GF, L1, L2 dan L3) dan 2 lantai bawah tanah (Basement 1 dan 2) yang digunakan untuk lapangan parkir. Walaupun BIP termasuk mall yang tertua di Bandung, namun karena letaknya di tengah kota dan banyak dilewati oleh transportasi publik, tidak menjadikan mall ini sepi pengunjung karena tergeser mall baru.

BIP juga berusaha meningkatkan pelayanan dengan keberadaan penyewa - penyewa yang tentunya akan dicari pengunjung mall. Tidak hanya terdiri dari pertokoan saja, mall ini juga dilengkapi dengan arena bermain anak, bioskop, tempat makan, dan lainnya.

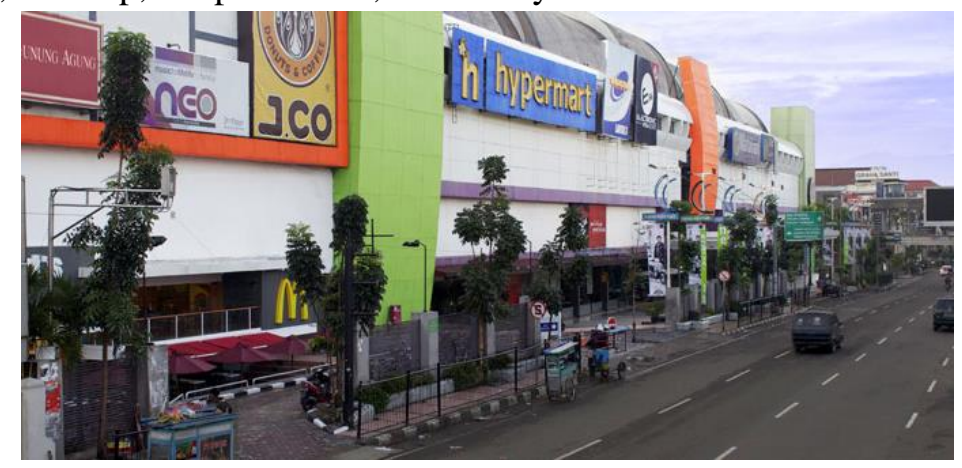

Gambar 6. Tampak depan Bandung Indah Plaza[9]

Pengunjung mall ini membidik pangsa pasar menengah ke atas. Terdapat 200 lebih gerai penyewa dari mulai ukuran kecil yang berupa kios, toko, sampai dengan penyewa besar yang bahkan mengambil area sampai 2 lantai, seperti pertokoan pakaian Matahari Department Store, Hypermart supermarket dan bioskop XXI.

Tetapi dibalik pelayanan yang diberikan, masih terdapat hal - hal yang kurang diperhatikan pihak pengelola dalam menyediakan fasilitas pelayanannya terutama untuk pengunjung yang menggunakan alat bantu berjalan. Untuk orang yang tidak membutuhkan alat bantu berjalan, hal ini mungkin tidak terasa kebutuhannya, namun tetap perlu untuk diperhatikan keberadaan fasilitas ini di tempat umum karena kebutuhan akan hiburan tidak hanya milik orang normal saja.

Kondisi lay out bangunan BIP saat ini adalah sebagai berikut: 

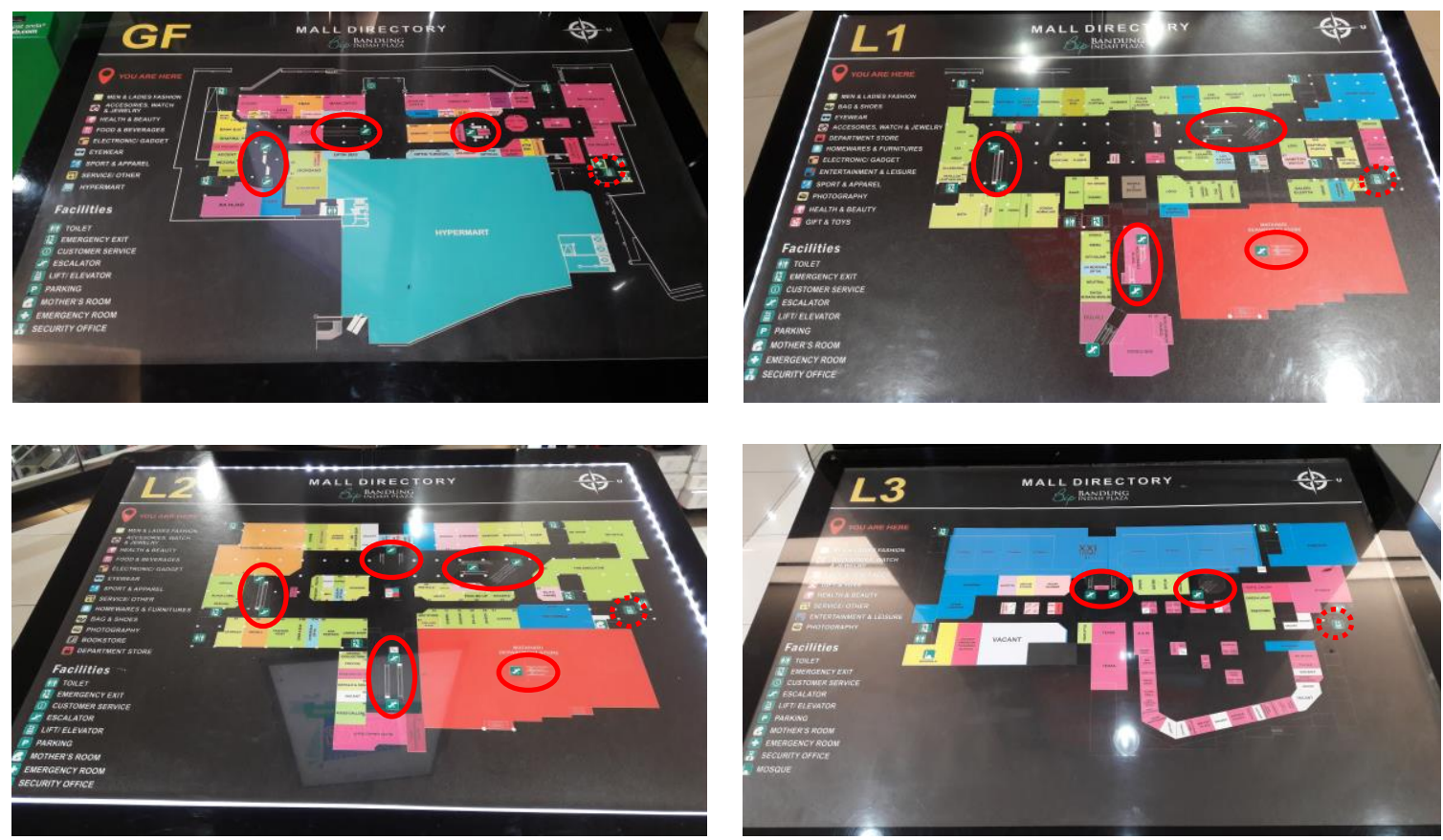

Keterangan gambar :

\section{Gambar 7. Lay Out BIP per Lantainya}

$\underset{\text { Lift }}{-} \quad$ Tangga berjalan (escalator)

Akses vertikal atau pencapaian ke tingkat berikutnya untuk pengunjung yang terdapat di BIP kebanyakan terdiri dari eskalator yang berada di beberapa titik per lantainya. Seperti terlihat pada mall directory (gambar 7), masing - masing lantai minimal mempunyai 2 titik eskalator yang tersebar. Hanya pada lantai P1 dari tempat parkir menuju ke ground floor saja terdapat ram (jalur melandai) yang memfasilitasi pengunjung yang membawa troli belanja dari Hypermart menuju ke tempat parkir.
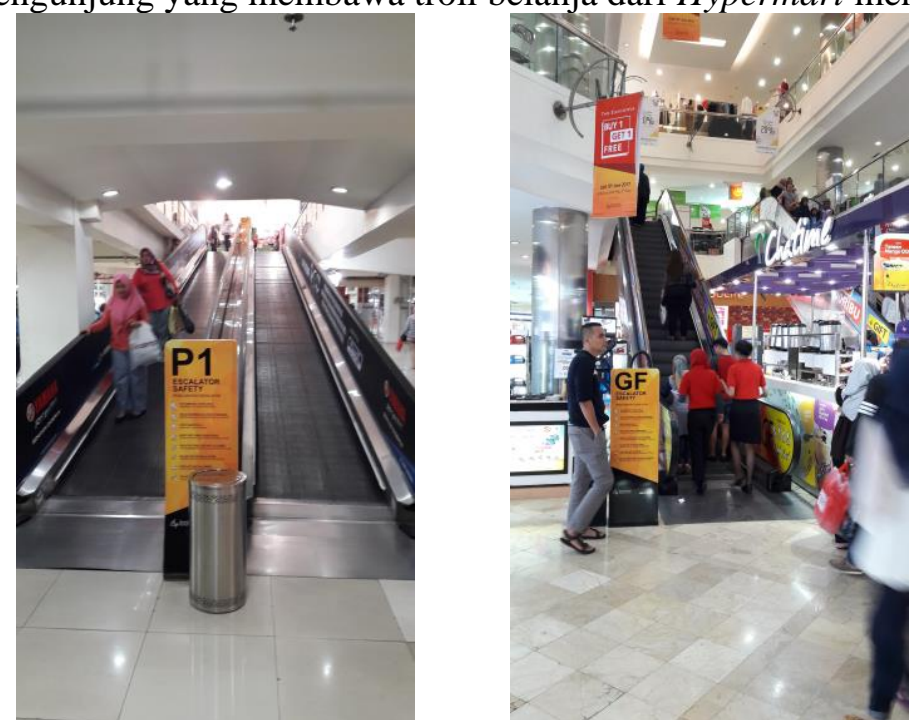

\section{Gambar 8. Ram dari lantai parkir \& eskalator mall}

Telah disinggung sebelumnya pada peraturan pemerintah di atas, bahwa bangunan yang lebih dari 5 lantai harus memiliki lift untuk memudahkan pengunjung dalam mencapai setiap lantai. Namun dengan total 6 lantai, mall ini hanya memiliki lift dari tempat parkir basement 1 dan 2, itu pun fungsinya lebih kepada memfasilitasi pengunjung yang membawa troli barang belanja dari supermarket yang terletak di lantai GF. 
Ram yang terletak antara lantai GF dan P1 pun ditujukan bukan untuk pengunjung dengan alat bantu berjalan, hal ini terlihat dari kemiringan ram yang lebih dari 5 derajat sehingga akan menyulitkan pengunjung dengan alat bantu ini naik ke ram tanpa bantuan orang lain, terutama untuk yang menggunakan kursi roda dan kereta bayi. Beban yang berlebihan akan dirasakan oleh pengguna kursi roda pada saat naik walaupun ram tersebut otomatis berjalan mengantarkan sampai dengan lantai berikutnya, dan mendorong kereta bayi juga akan terasa sangat berat. Walaupun kursi roda dan kereta bayi biasanya memiliki roda yang dapat dikunci, namun tetap membutuhkan bantuan orang lain dengan menahan alat bantu tersebut di belakangnya untuk menghindari merosot dari ram (gambar 8).

BIP sebenarnya mempunyai lift yang dapat memudahkan pengunjung dengan alat bantu berjalan untuk mencapai tingkat tertentu, namun lift ini fungsi utamanya adalah untuk mengangkut barang. Hal ini dapat dilihat dengan keberadaan lift tersebut tidak berada di atrium atau ruang tengah terbuka mall, melainkan berada di ujung pinggir bangunan yang biasanya di gunakan untuk servis loading barang. Apabila pengunjung ingin menggunakan lift ini, maka harus melewati akses yang berliku yang cukup sulit untuk ditemukan karena letaknya agak tersembunyi seperti terlihat pada gambar 7 dan 9 .
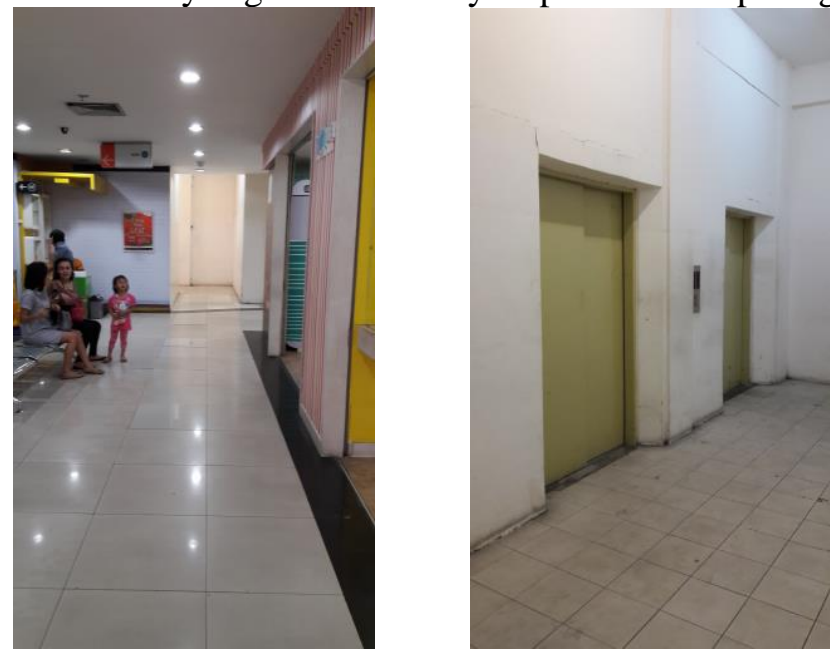

Gambar 9. Akses menuju lift \& lift barang

Sebaiknya apabila lift bersatu untuk barang dan pengunjung dengan alat bantu berjalan, besar dari lift tersebut harus bisa mengakomodasi keduanya pada saat yang bersamaan, juga letak lift tersebut mudah untuk di akses. Contohnya seperti lift pada rumah sakit yang cukup besar untuk mengangkut pengunjung, kursi roda bahkan tempat tidur pasien. Lift yang seperti ini biasanya mempunyai kapasitas sampai dengan 12 pengunjung.

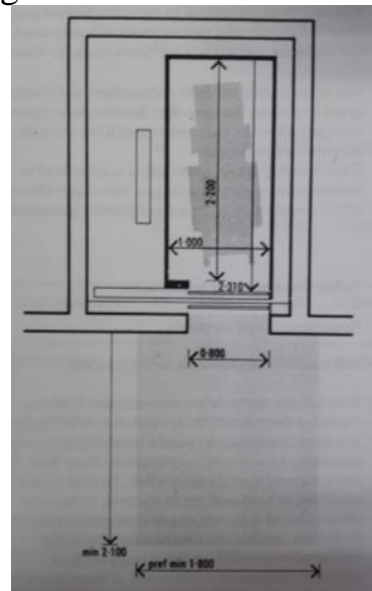

\section{Gambar 10. Contoh lift yang dapat memuat kursi roda dan barang[8]}

Namun yang lebih ideal adalah lift barang dan pengunjung dipisahkan penempatannya, karena memang lokasi dan kegunaannya juga berbeda - beda. 


\section{SIMPULAN \& SARAN}

Dari pembahasan diatas, kebutuhan aksesibilitas untuk pengunjung dengan alat bantu berjalan tentu akan jauh lebih dibutuhkan dibandingkan dengan orang yang tidak mempunyai keterbatasan fisik. Selain memudahkan mereka untuk mengunjungi suatu tempat di publik, juga akan membuat mereka mandiri dengan keterbatasannya. Dengan penyediaan fasilitas yang dibangun khusus untuk pengunjung dengan alat bantu berjalan juga akan membuat mereka lebih percaya diri karena merasa diperhatikan oleh lingkungan sekitar.

\section{DAFTAR PUSTAKA}

[1] https://idtesis.com/pengertian-aksesibilitas-adalah/, diakses tanggal 5 September 2017

[2] http://www.definisimenurutparaahli.com/pengertian-difabel-dan-disabilitas/, diakses tanggal 13 Juni 2017

[3] https://sebandung.com/2015/04/bandung-indah-plaza-tempat-hiburan-mengasyikan-di-kotabandung/, diakses tanggal 4 September 2017

[4] uu_nomor_8_tahun_2016, diakses tanggal 12 Juni 2017

[5] Infodatin Disabilitas (2014), diakses tanggal 12 Juni 2017

[6] http://www.chiccoshop.com/gear/strollers/lightweight/; diakses tanggal 15 Juni 2017

[7] http://pelayanan.jakarta.go.id/download/regulasi/keputusan-menteri-pekerjan-umum-repubukindonesia-nomor-468-kpts-1998-tentang-persyaratan-teknis-aksesibilitas-pada-bangunan-umumdan-lingkungan.pdf, diakses tanggal 21 Juni 2017

[8] Selwyn Goldsmith (1976), Designing for The Disabled, RIBA Publications Limited, England, pp.171, 221

[9] http://anekatempatwisata.com/8-mall-di-bandung-yang-wajib-dikunjungi/, diakses tanggal 15 Juni 2017 